\title{
Endo-antral syndrome in aspergillosis
}

\author{
Sindromul endo-antral în aspergiloză
}

\section{Alexandru Andrei Iliescu'1, Paula Perlea², Sînziana Adina Scărlătescu², Irina Maria Gheorghiu ${ }^{3}$}

\author{
${ }^{1}$ Disciplina de Reabilitare orală, Facultatea de Medicină Dentară, \\ Universitatea de Medicină şi Farmacie, Craiova, România \\ ${ }^{2}$ Disciplina de Endodonţie, Facultatea de Medicină Dentară, \\ Universitatea de Medicină şi Farmacie „Carol Davila“, Bucureşti, România \\ ${ }^{3}$ Disciplina de Odontoterapie Restauratoare, Facultatea de Medicină Dentară, Universitatea de \\ Medicină şi Farmacie „Carol Davila“, Bucureşti, România
}

\begin{abstract}
While initiating an endo-antral syndrome, inside the endodontic system and the chronic apical lesions of upper teeth anatomically related to the maxillary sinus floor, may be found both endopathogenic bacteria and filamentous fungi. Similarly the improper root canal treatments may facilitate an emerging aspergillosis of maxillary sinus. By phenotype and genotype analysis in $10 \%$ of chronic apical periodontitis were disclosed filamentous fungi of Aspergillus genus ( $A$. fumigatus, $A$. versicolor and $A$. niger). Accordingly might be also taken into consideration the hypothesis of mutual pathogenical relationship between pulpal and sinusal pathology, since at its turn the aspergillosis of maxillary sinus can also promote the contamination of already filled or still untreated necrotic root canals with filamentous fungi.

Keywords: endo-antral syndrome, chronic apical periodontitis, chronic maxillary sinusitis, aspergillosis

\section{REZUMAT}

În declanşarea sindromului endo-antral, alături de bacteriile endopatogene, în sistemul endodontic şi leziunile cronice apicale ale dinţilor sinuzali se pot întâlni şi ciuperci filamentoase, după cum tratamentele endodontice impropriu conduse pot facilita debutul unei aspergiloze a sinusului maxilar. Analizele fenotipice şi genotipice au evidenţiat ciuperci filamentoase din genul Aspergillus (A. fumigatus, $A$. versicolor şi $A$. niger) în $10 \%$ dintre dinţii cu parodontite apicale cronice. Din această perspectivă se emite şi ipoteza relaţiei etio-patogenice cu dublu sens între patologia endodontică şi cea sinuzală, întrucât la fel de bine şi o aspergiloză a sinusurilor maxilare poate cauza însămânţarea cu ciuperci filamentoase a unor canale radiculare deja obturate sau încă netratate în care ţesutul pulpar s-a mortificat.
\end{abstract}

Cuvinte cheie: sindrom endo-antral, parodontită apicală cronică, sinuzită maxilară cronică, aspergiloză

\section{INTRODUCERE}

Sindromul endo-antral a fost descris în premieră încă din 1943 de Bauer, pe baza unor studii histopatologice, ca manifestare clinică a propagării patologiei parodonțiului apical la sinusurile maxilare (1).

Infecțiile odontogene ale dinţilor superiori cu rapoarte anatomice sinuzale explică $10-12 \%$ dintre sinuzitele maxilare cronice generate de propagarea microorganismelor şi toxinelor prin anastomozele vasculare şi vasele limfatice de vecinătate sau prin medulara crestelor alveolare, grație contactului strâns oferit cu precădere de rădăcinile palatinale ale molarilor $(2,3)$.

În declanşarea sindromului endo-antral, parodontitele apicale şi marginale cronice localizate la aceşti dinţi au o pondere de $83 \%$, restul de $17 \%$ ai factorilor etiologici fiind reprezentați de biofilmul microbian din gangrena pulpară sau flora reziduală 
a canalelor radiculare deja tratate $(2,4)$. Există o corelație directă între parodontitele apicale cronice şi îngroşarea mucoasei sinuzale în urma instalării inflamației cronice conexe (5).

S-a dovedit, de asemenea, că, alături de bacteriile endopatogene, în sistemul endodontic şi leziunile cronice apicale ale dinților sinuzali se pot regăsi şi ciupercile filamentoase $(2,6,7)$, după cum tratamentele endodontice impropriu conduse pot facilita debutul unei aspergiloze a sinusului maxilar $(2,8,9)$.

\section{ETIOPATOGENIE}

Un studiu recent a evidențiat ciuperci filamentoase din genul Aspergillus în 10\% dintre dinții cu parodontite apicale cronice având tratamentul endodontic finalizat în ultimii 3 ani. Analizele fenotipice şi genotipice au precizat următoarele proporții ale speciilor de ciuperci: $A$. fumigatus $1,6 \%, A$. versicolor $1,6 \%$ şi $A$. niger $6,7 \%$ (2).

Faptul că s-au găsit specii de Aspergillus în canalele radiculare ale dinților sinuzali cu obturații de canal atrag atenția asupra infecțiilor odontogene ca o a doua cale de inoculare sinuzală a acestor ciuperci filamentoase, în afara celei preponderente, aerogenă, de mult demonstrată (2).

Pornind de la favorizarea creşterii speciilor de Aspergillus în prezența zincului, un argument în plus al factorului de risc odontogen, în afara vehiculării microorganismului, este dat de conținutul în oxid de zinc al multor cimenturi de sigilare folosite pentru tratamentul endodontic, care poate ajunge în sinusul maxilar deja infectat pe căile de comunicare anatomice existente, întreținând dinamica metabolică a ciupercilor (2).

Din această perspectivă, se emite şi ipoteza relației etiopatogenice cu dublu sens între patologia endodontică şi cea sinuzală, întrucât la fel de bine şi o aspergiloză a sinusurilor maxilare poate cauza însămânțarea cu ciuperci filamentoase a unor canale radiculare deja obturate sau încă netratate în care țesutul pulpar s-a mortificat (2).

\section{SIMPTOMATOLOGIE CLINICĂ}

Simptomatologia clinică simulează o sinuzită maxilară cronică, putând fi exprimată prin jenă dureroasă difuză în zona geniană, obstrucție nazală și secreții nazale purulente, cacosmie, iar uneori şi prin epistaxis, cefalee şi stare febrilă (10-13).

Este prezentă în unele cazuri şi o uşoară infilttrare nedureroasă a regiunii geniene, fără modificarea de culoare a tegumentelor, cu extindere infraorbitală şi spre baza piramidei nazale din cauza erodării peretelui anterior al cavitătii sinuzale, care duce la afectarea țesutului subcutanat (10-13). Totuşi, nu există adenopatie loco-regională (14).

Rinoscopia anterioară poate evidenția congestia mucoasei nazale, devierea septului nazal de partea opusă, o masă necrotică de ciuperci şi depozite purulente în meatusul mijlociu. La rinoscopia posterioară de regulă nu se observă modificări locale.

S-au descris şi aspergiloze sinuzale de natură iatrogenă, după obturațiile de canal, dintele în cauză putând fi sensibil la masticație sau percuție axială, dar fără a exista vreo asimetrie facială prin tumefierea obrazului (11).

Alte iatrogenii potențial implicate în apariția unei aspergiloze a sinusurilor maxilare sunt şi accidentele de extracție, cu pătrunderea în cavitatea sinuzală a restului radicular rezultat $(11,12,14-16)$. Postextracțional s-au descris în anumite cazuri şi constituirea unor fistule oro-antrale (11).

În urma eșecului extracției unui rest radicular aparținând unui dinte sinuzal, precum al doilea premolar superior, al cărui tratament endodontic a fost compromis, s-a descris o tumefacție geniană dureroasă cu persistența şi chiar extinderea durerii în zona faringiană, însoțită de disfagie (11). Ameliorarea evidentă a tabloului clinic s-a constatat la 3 luni, iar vindecarea completă - după 6 luni de tratament general cu itraconazol (11).

Nici pătrunderea accidentală a unor corpi străini în cavitatea sinuzală nu trebuie subestimată, deoarece generează o sinuzită cronică, indiferent dacă se asociază sau nu cu o fistulă oro-antrală care potențează pătrunderea microrganismelor din flora orală (16).

Natura corpilor străini sinuzali este extrem de variată. În afara materialelor de obturație de canal şi a resturilor radiculare deja menţionate, mai pot pătrunde freze, ace, implanturi dentare sau materiale de amprentă (16-20).

Foarte rar şi numai când sunt minusculi, corpii străini pot fi transportaţi de epiteliul ciliat sinuzal şi expulzați în fosele nazale prin ostium. De regulă, pentru a permite retrocedarea inflamației mucoasei sinuzale, este însă necesară îndepărtarea lor chirurgicală (16). 


\section{EXAMENE COMPLEMENTARE}

Radiologic, pe ortopantomografie, sinusul maxilar afectat apare radioopac (10). În formele invazive mai avansate de aspergiloză, examenul CT evidențiază o masă de hipodensitate care expandează cavitatea sinuzală, fiind însoțită de distrucții ale peretelui nazal şi apariția unor zone parțial opacifiate $(21)$.

În aspergiloza sinusurilor maxilare, examenul radiologic ortopantomografic evidențiază aspecte tipice, traduse prin apariția unor corpi radioopaci rotund-ovalari unici sau multipli, ca rezultat al precipitării unor săruri minerale de fosfat tricalcic sau sulfat de calciu în zonele necrozate ale miceliilor $(14,15,22,23)$.

Pentru evitarea confuziilor diagnostice ridicate de aceste imagini radioopace, se recomandă efectuarea unei densitometrii CT, dovedindu-se că, în cazul unor valori care depăşesc $1.500 \mathrm{Hu}$, ne confruntăm cu o aspergiloză sinuzală consecutivă obturațiilor de canal cu depăşire, în timp ce, la valori mai mici de $1.500 \mathrm{Hu}$, este vorba de un aspergilom propriu-zis, format exclusiv dintr-un material organic care nu conține oxid de zinc $(14,24)$. De altfel, examenul CT pune în evidență ca o abatere de la normalitate atât o masă de țesut moale, cât şi o zonă dens radioopacă bine conturată (15).

În afara hiperplaziei mucoasei şi a prezenței unei mase radioopace în cazul unor fistule oro-antrale, examenul CT evidențiază un contur osos neregulat şi discontinuitatea podelei cavităţii sinuzale (11).

În aspergiloza satelită obturațiilor de canal cu depăşire, care au penetrat podeaua cavităţii sinuzale, examenul radiologic evidenţiază un corp radioopac dens bine conturat, un antrolit, situat central în cavitatea sinuzală sau în apropierea hiatusului semilunar (14).

Examenele de laborator pun în evidență prezența crescută față de valorile normale $(<0,5 \mathrm{mg} / \mathrm{dl})$ a proteinei $\mathrm{C}$ reactive $(1,2-3,4 \mathrm{mg} / \mathrm{dl})(21)$.

In cazul sindromului endo-antral din aspergiloză, cauzat de împingerea în sinus a unui rest radicular aparținând unui dinte cu tratament endodontic compromis, țesutul recoltat postextracțional din alveolă evidenţiază numeroşi spori şi hife septate de Aspergillus (11).

\section{FORME CLINICE}

Este cunoscut că cea mai frecventă formă clinică de aspergiloză se localizează în plămâni. În acest context, aspergiloza sinusurilor maxilare este o afecțiune destul de rară la indivizii cu o stare bună de sănătate generală. Creşterea hifelor poate dura chiar ani de zile până când ocupă în totalitate cavitatea sinuzală (10).

Forma clinică neinvazivă, denumită aspergilomul sinusurilor paranazale sau „ciuperca minge“, afectează unilateral sinusurile maxilare. Întâlnită de regulă la indivizii sănătoşi, poate fi simptomatică sau asimptomatică, simulând sinuzita cronică. Aspergilomul este alcătuit dintr-o masă compactă de ciuperci, detritusuri tisulare şi leucocite extravazate.

Radiologic, se caracterizează printr-o radioopacitate sinuzală unilaterală de densitate crescută (antrolit), care poate fi o reacție de corp străin declanşată de o obturație de canal preexistentă cu depăşire, ale cărei materiale (sigilanți pe bază de oxid de zinc-eugenol) au pătruns în cavitatea sinuzală (14).

Forma clinică invazivă, specifică indivizior imunocompromişi, este categoric mai severă şi frecvent eronat diagnosticată; mai rară cu ceva timp în urmă, în prezent incidenţa sa este în creștere (25). Se întâlneşte de regulă numai la indivizii imunocompromişi, fiind caracterizată prin evoluţie progresivă rapidă cu necroză tisulară gangrenoasă a mucoperiostului şi rezorbție osoasă destructivă (10).

S-au descris şi cazuri de complicaţie cu osteomielita sinusului maxilar cauzate de specia $A$. tubingensis, un patogen oportunist aparținând grupării de suşe înrudite filogenetic de A. niger, identificată prin tehnica moleculară de identificare a secvenței genei $\beta$-tubilinei (26).

Prin extindere, leziunea cu debut sinuzal avansează intraorbital, manifestându-se prin chemoză şi tulburări oculare finalizate prin pierderea vederii, precum şi intracranian, de-a lungul bazei craniului şi formațiunilor vasculare, generând tromboza sinusului cavernos şi complicaţii neurologice (25).

Dintre formele clinice invazive de aspergiloză sinuzală fac parte:

- sinuzita acută invazivă, cu debut de bronhopneumonie necrotică instalată pe fond neutropenic, rezorbție osoasă distructivă a pereților 
cavității sinusale şi evoluție rapidă letală în formele fulminante (25\% dintre cazuri) (14).

- sinuzita cronică invazivă, preponderent întâlnită în diabetul zaharat sau corticoterapia prelungită (14).

Forma clinică alergică, care se întâlneşte la pacienții tineri cu polipi nazali sau astm bronşic în antecedente, manifestându-se clinic similar traheobronşitei alergice. Simptomatologia sinuzală, în care există obstrucție nazală, este asemănătoare formei neinvazive de aspergiloză, dar nu răspunde la tratamentul convențional (14).

Se pare că asocierea aspergilozei alergice bronhopulmonare cu forma alergică de aspergiloză a sinusurilor maxilare, deşi atinge cca. $10 \%$ dintre cazuri, este trecută cu vederea, deoarece de regulă pacientul este examinat separat pentru afecțiunea pulmonară, respectiv cea maxilofacială (13).

Aspergiloza alergică bronhopulmonară cu care se poate asocia această formă alergică de aspergiloză sinuzală este cauzată de hipersensibilitatea la $A$. fumigatus $(13,28)$. Ea apare la pacienții cu fibroză chistică (2-15\%) sau astm cronic (1-2\%), manifestându-se prin semne şi simptome nespecifice precum: astm bronşic, bronşiectazie centrală, infiltrate pulmonare recidivante şi activare imună sistemică cu eozinofilie în circulația periferică, valori serice crescute ale $\operatorname{IgE}$ totale $(>1.000 \mathrm{IU} / \mathrm{ml})$, prezența IgE specifice la $A$. fumigatus ( $>0,35 \mathrm{kU} / \mathrm{I})$ şi pozitivarea IgG la antigenul de Aspergillus (13).

\section{BIBLIOGRAFIE}

1. Hauman C.H.J., Chandler N.P., Tong D.C. Endodontic implications of the maxillary sinus: a review. Int Endod J 2002; 35(2):127-141.

2. Gomes C.C., Costa Pinto L.C., Loretti Victor F., da Silva E.A.B., de Aguiar Ribero A., de Moura Sarquis M.I., Coelho Gomes Camoes I. Aspergillus in endodontic infections near the maxillary sinus. Braz J Otorhinolaryngol 2015; 81(5)527-532.

3. Tataryn R.W. Rhinosinusitis and endodontic disease. In: Ingle JI, Bakland LK, Baumgartner JC (eds). Ingle's endodontics. $6^{\text {th }}$ edition, BC Decker, Hamilton, Canada, 2008, 626-637.

4. Kretzschmar D.P., Kretzschmar J.L., Salem W. Rhinosinusitis: review from a dental perspective. Oral Surg Oral Med Oral Pathol Oral Radiol Endod 2003; 96(2):128135.

5. Lu Y., Liu Z., Zhang L., Zhou X., Zheng Q., Duan X., Zheng G., Wang H., Huang D. Association between maxillary sinus mucosal thickening and apical periodontitis using cone-beam

\section{EVOLUŢIE}

Ca mers clinic evolutiv, aspergiloza maxilară poate îmbrăca un aspect colonizant, neinvaziv, sau unul invaziv. Forma colonizantă apare la indivizii cu stare generală bună, manifestându-se ca o sinuzită maxilară obişnuită care nu răspunde însă la antibioterapie. Examenul radiologic arată o radioopacitate sinuzală, dar nu pune în evidență leziuni osoase resorbtive ale pereților cavității sinuzale (10). Se constată totuşi o atrofie a mucoasei şi a pereților osoşi ai cavității sinuzale (25).

\section{DIAGNOSTIC POZITIV}

Diagnosticul pozitiv se pune prin examenul histopatologic şi însămânţarea pe medii de cultură (25).

\section{DIAGNOSTIC DIFERENȚIAL}

Diagnosticul diferențial al aspergilozei invazive se face cu: sinuzita micotică alergică, mucormicoza, mucopiocelul, tumorile benigne şi maligne, limfoamele, tuberculoza, luesul, sarcoidoza, granulomatoza Wegener şi manifestările maxilo-faciale induse de Pseudomonas $(25,27,28)$.

\section{MENTIUNI}

Toți autorii au contribuție egală în realizarea articolului.

Conflict of interest: none declared Financial support: none declared

computed tomography scanning: a retrospective study. J Endod 2012; 38(8):1069-1074.

6. Gomes C., Fidel S., Fidel R., de Moura Sarquis M.I. Isolation and taxonomy of filamentous fungi in endodontic infections. J Endod 2010; 36(4):626-629.

7. Mensi M., Salgarello S., Pinsi G., Piccioni M. Mycetoma of the maxillary sinus: endodontic and microbiological correlations. Oral Surg Oral Med Orl Pathol Oral Radiol Endod 2004; 98(1):119-123.

8. Mensi M., Piccioni M., Marsili F., Nicolai P., Sapelli C.L., Latronico N. Risk of maxillary fungus ball in patients with endodontic treatment on maxillary teeth: a case-control study. Oral Surg Oral Med Orl Pathol Oral Radiol Endod 2007; 103(3):433-436.

9. Park G.Y., Kim H.Y., Young Min J., Dhong H.J., Chung S.K. Endodontic treatment: a significant risk factor for the development of maxillary fungal ball. Clin Exp Otorhinolaryngol 2010;3(3):136-140. 
10. Agarwal M.K., Shukla P.K. Aspergillosis of the maxillary sinus. IJO \& HNS 1998; 50(1):43-45.

11. Urs A.B., Singh H., Nunia K., Mohanty S., Gupta S. Post endodontic aspergillosis in an immunocompetent individual. J Clin Exp Dent 2015; 784):e535-539.

12. Guivarc'h M., Ordioni U., Catherine J.H., Campana F., Camps J., Bukiet F. Implications of endodontic-related sinus aspergillosis in a patient treated by infliximab: a case report. J Endod 2015; 41(1):125-129.

13. Mohindra S., Mehta R., Bal A. ABPA concomitantly occuring with invasive sinus aspergillosis: a short report on two patients. Indian J Otolaryngol Head Neck Surg 2014; 66(Suppl 1):S329-S333.

14. Khongkhunthian P., Reichart P.A. Aspergillosis of the maxillary sinus as a complication of overfilling root canal material into the sinus: report of two cases. J Endod 2001; 27(7):476-478.

15. Giardino L., Pontieri F., Savoldi E., Tallarigo F. Aspergillus mycetoma of the maxillary sinus secondary to overfilling of a root canal. J Endod 2006; 32(7):692-694.

16. Tanasiewicz M., Bubilek-Bogacz A., Twardawa H., Skucha-Nowak M., Szklarski T. Foreign body of endodontic origin in the maxillary sinus. J Dent Sci 2017; 12:296-300

17. Linston P.N., Walters R.F. Foreign bodies in maxillary antrum: a case report. Aust Dent J 2002; 47(4):344-346.

18. Harada T., Isomura E.T., Uchihashi T., Kogo M. Aspergillosis associated with migration of a dental implant into the maxillary sinus: a case report. J Oral Maxillofac Surg Med Pathol 2017; 29(5):448-451.

19. lida S., Tanaka N., Kogo M., Matsuya T. Migration of a dental implant into the maxillary sinus: a case report. Int J Oral Maxillofac Surg 2000; 29(5):358-359.

20. Sgaramella N., Tartaro G., D'Amato S., Santagata M., Colella G. Displacement of dental impants into the maxillary sinus: a retrospective study of twenty-one patients. Clin Implant Dent Relat Res 2016; 18(1):62-72.

21. Kiriyama T., Murayama S.Y., Myoken Y. Confirmatory diagnosis of invasive maxillary sinus aspergillosis by in situ hybridization: report of two cases in immunocompetent subjects. J Oral Maxillofac Surg Med Pathol 2012; 24(2):124-127.

22. Stammberger H., Jakse R., Beaufort F. Aspergillosis of the paranasal sinuses. Radiology 1985; 156(3):715-716.

23. Tanaka H., Sakae T., Mishima H., Yamamoto H. Calcium phosphate in aspergillosis of the maxillary sinus. Scan Microscop 1993; 7(4):1241-1246.

24. Krennmair G., Lenglinger F. Maxillary sinus aspergillosis: diagnosis and diferentiation of the pathogenesis on computed tomography densitometry of sinus concretions. J Oral Maxillofac Surg 1995;53(6):657-663.

25. Peral-Cagigal B., Redondo-Gonzalez L.M., VerrierHernandez A. Invasive maxillary sinus aspergillosis: a case report succesfully treated with voriconazole and surgical debridement. J Clin Exp Dent 2014; 6(4):e448-451.

26. Bathoorn E., Escobar Salazar N., Sepehrzad S., Meijer M., de Cock H., Haas P.J. Involvement of the opportunistic pathogen Aspergillus tubingensis in osteomyelitis of the maxillary bone: a case report. BMC Infectious Diseases 2013; 13:59.

27. Sharma D., Mahajan N., Rao S., Khurana N., Jaun S. Invasive maxillary aspergillosis masquerading as malignancy in two cases: utility of cytology as a rapid diagnostic tool. J Cytol 2012; 29(3):194-196.

28. Shah A. Allergic bronchopulmonary aspergillosis: an Indian perspective. Curr Opin Pulm Med 2007; 13(1):72-80. 